\title{
A Risk Infection Simulation Model for Fusarium Head Blight of Wheat
}

\author{
Emerson M. Del Ponte ${ }^{1 *}$, José Maurício C. Fernandes ${ }^{1} \&$ Willingthon Pavan ${ }^{2}$ \\ ${ }^{1}$ Embrapa Trigo, Rodovia BR 285, km 174, Cx. Postal 451, Passo Fundo, RS, e-mail: edelponte@ gmail.com, \\ mauricio@cnpt.embrapa.br; ${ }^{2}$ Instituto de Ciências Exatas e Geociências, Curso de Ciência da Computação, \\ Universidade de Passo Fundo, BR 285 Km 171, São José, CEP 99001-970, Passo Fundo, RS, e-mail: pavan@upf.br
}

(Aceito para publicação em 24/06/2005)

Corresponding author: José Maurício Fernandes

DEL PONTE, E.M., FERNANDES, J.M.C. \& PAVAN, W. A risk infection simulation model for Fusarium head blight of wheat. Fitopatologia Brasileira 30:634-642. 2005.

\begin{abstract}
Fusarium Head Blight (FHB) is a disease of great concern in wheat (Triticum aestivum). Due to its relatively narrow susceptible phase and environmental dependence, the pathosystem is suitable for modeling. In the present work, a mechanistic model for estimating an infection index of FHB was developed. The model is process-based driven by rates, rules and coefficients for estimating the dynamics of flowering, airborne inoculum density and infection frequency. The latter is a function of temperature during an infection event (IE), which is defined based on a combination of daily records of precipitation and mean relative humidity. The daily infection index is the product of the daily proportion of susceptible tissue available, infection frequency and spore cloud density. The model was evaluated with an independent dataset of epidemics recorded in experimental plots (five years and three planting dates) at Passo Fundo, Brazil. Four models that use different factors were tested, and results showed all were able to explain variation for disease incidence and severity. A model that uses a correction factor for extending host susceptibility and daily spore cloud density to account for post-flowering infections was the most accurate explaining $93 \%$ of the variation in disease severity and $69 \%$ of disease incidence according to regression analysis.
\end{abstract}

Additional keywords: Fusarium graminearum, plant disease modeling, disease forecast.

\section{RESUMO}

Um modelo de simulação do risco de infecção da giberela do trigo

O curto período relativo de suscetibilidade da planta e a dependência ambiental, fazem com que epidemias de giberela do trigo possam ser modeladas matematicamente. No presente trabalho, foi desenvolvido um modelo mecanístico para previsão da epidemia de giberela. O modelo é dividido em sub-processos, os quais são governados por taxas, regras e coeficientes que definem: progresso do espigamento; extrusão de anteras; densidade de inóculo aéreo e frequência de infecção. Esta última é influenciada pela temperatura durante a ocorrência de evento de infecção (EI). A combinação de dados diários de precipitação e umidade relativa média é que determina a ocorrência do EI. O índice diário de infecção é calculado em função da proporção de tecido suscetível presente, frequiência de infecção e densidade da nuvem de esporos, durante cada EI. A avaliação do modelo foi feita com dados de cinco anos de epidemia variando de não epidemica a severa epidemia observada na localidade de Passo Fundo. Quatro modelos que combinam diferentes fatores foram avaliados. Todos os modelos explicaram consideravelmente a variação da incidência e severidade. Um modelo que utiliza um fator de correção no hospedeiro para contabilizar infecções após o florescimento um outro fator para a densidade diária da nuvem de esporos, produziu estimativas mais acuradas, explicando 93\% da variação da severidade da doença e $69 \%$ da variação de incidência, conforme sugerido pela análise de regressão.

Palavras-chave adicionais: Fusarium graminearum, modelagem de doenças de plantas, previsão de epidemias, simulação de sistemas.

\section{INTRODUCTION}

Fusarium head blight (FHB) of wheat (Triticum aestivum L.), also called wheat scab, is an important disease throughout much of the world's wheat-growing areas where severe epidemics have been reported in recent years (McMullen et al., 1997). Several Fusarium species can cause head blight, although Gibberella zeae Schwain (Petch.)

* Bolsista do CNPq (anamorph Fusarium graminearum Schwabe) is the predominant pathogen in most growing regions and has been reported as the main causal agent in Brazil (Reis, 1986; Bottalico \& Perrone, 2002). The FHB emerged in Brazil as an important disease in recent years promoting serious yield losses (Panisson et al., 2003). Wheat contamined with deoxynivalenol (DON) in excess of permitted levels results in rejection of sale or severe price dockage by millers and other grain buyers in some countries that have adopted DON regulation (Schaafsma et al., 2001). 
Giberella zeae is a facultative saprophyte with an important part of its cycle occurring in crop residue, which serves as the main reservoir for inoculum that leads to infection (Sutton, 1982). It has been stated that monoculture, reduced tillage, and maize-wheat rotations have greatly increased inoculum levels in soil (Miller et al., 1998). The FHB is best known as a flowering disease with anthers as the primary infection site where fungus spores land and then grow into the kernels, glumes or other spike tissues (Sutton, 1982; McMullen et al., 1997). Some evidence suggests wheat may be susceptible up through the soft dough stage of kernel development (Andersen, 1948; Fernando et al., 1997). Although post-flowering infections may have a low impact on crop yield, infected and DON-contaminated plump kernels are likely to contribute to the final mycotoxin levels in mature grains (Hart et al., 1984; Del Ponte et al., 2003).

Although research progress has been made for decades, disease control is still challenging due to the complex disease nature. The FHB still poses a significant threat to yield, quality of wheat and other small grains (McMullen et al., 1997). Most cultivars do not possess desirable levels of resistance that could lead to good genetic control (Lima et al., 2000; Bai et al., 2001). Breeding for wheat scab resistance is a long, difficult task, but some progress has been accomplished (Mesterhazy, 1997; Bai et al., 2000). A range of fungicides has been identified with good activity against the pathogen, but dose rate, application timing and spray quality for adequate coverage of the spike tissues are critical for control efficacy in the field (Reis et al., 1996; Picinini \& Fernandes, 2001). Others have stressed that inconsistent success with fungicide treatments may occur due to a lack of disease forecasting information (McMullen et al., 1997). The development of a forecasting system has been suggested as an important tool to be integrated into FHB management to effectively use fungicides in conjunction with other management strategies (McMullen et al., 1997; Xu, 2003). Regarding the development of FHB prediction models, different modeling approaches are found in the literature. Correlation and regression studies among environmental variables and historical records of some disease variables have led to the development of empirical regression models. On the other hand, process-oriented simulation models have been proposed as well. Detailed information on several FHB models has been reviewed recently (Del Ponte et al., 2004b).

The aims of this work were to develop a processbased risk infection simulation model for estimating FHB epidemics in a location in Southern Brazil and to evaluate the performance of the model in explaining disease observed for five years at the same location.

\section{MATERIAL AND METHODS}

The present model, GIBSIM, is a significant improvement over previous efforts for developing a phenology-based FHB simulation model (Vargas et al., 2000; Fernandes \& Pavan, 2002). Several components were added and/or modified by the inclusion of functions, rules and environmental variables supported by local experimentation and data from the literature. Briefly, the model aims to calculate the proportion of tissue infected taking into account the dynamics of the host, environment and inoculum during an infection event.

\section{Model description}

A diagram for the model is presented in Figure 1 according to the principles of system analysis. Simulation is initiated when the first heads fully emerge in the field (FHE). The daily proportion of heads emerged (HEMG) is a function of the heading rate (HNG). Anther's extrusion rate (EXT) calculates the daily proportion of extruded anthers in a cohort of heads. The coupling of a heading model, an anther extrusion model and a rule for anther longevity, determines the daily proportion of anthers exposed (ANT), which translates into susceptible tissue ( $\mathrm{ST}=\mathrm{ANT}$ ). Inoculum is assumed to be present on the residues (IRES). The density of an airborne G. zeae spore cloud (GZ) is a function of dispersal rate (DIS). An infection event (IE) is determined based on a combination of rainfall and relative humidity in a two-day window. Infection frequency (INF) is a function of average mean daily temperature in the twoday window of the IE. The daily infection risk index (GIB) is the product of the proportion of susceptible tissue (ST), infection frequency (INF) and G. zeae spore cloud density (AGZ). Rates and rules in the models are influenced by daily weather variables such as mean temperature (T), solar radiation (RAD), relative humidity $(\mathrm{RH})$ and precipitation (PREC).

\section{Model structure}

Host factor: A Weibull function was empirically adjusted to the daily cumulative proportion of heads emerged (HNG) observed in a 1-meter section of several Brazilian spring wheat varieties (Del Ponte et al., 2004a).

$$
\mathrm{HNG}=1-\exp \left(-0.0127 t^{2.4352}\right)
$$

\section{Where: $t=1$ day}

The HNG calculates groups of heads (cohort) emerged in the same day and it is assumed that each cohort partially emerged (code 55 - Zadoks et al., 1974) has its first anthers extruded three days later. The daily rate of cumulative proportion of extruded anthers in a cohort of heads (ANText) is calculated by another Weibull function, which parameters' values vary according to the daily mean temperature [2] (Del Ponte et al., 2004b).

$$
\mathrm{ANText}=1-\exp \left(\mathrm{a} t^{\mathrm{b}}\right)
$$

Where $t=1$ day; $\mathrm{a}=0.255-0.029 \mathrm{~T}+0.0009 \mathrm{~T}^{2} ; \mathrm{b}=-5.773+$ $0.966 \mathrm{~T}-0.0278 \mathrm{~T}^{2}$; where: $\mathrm{T}=$ Daily mean temperature $\left({ }^{\circ} \mathrm{C}\right)$ 


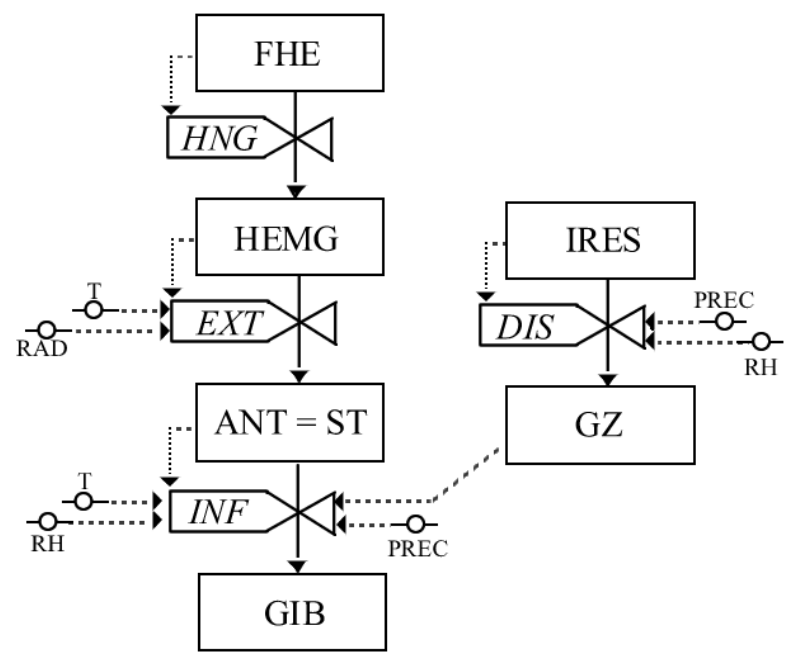

FIG. 1 - Relational diagram of GIBSIM a mechanistic model estimating risk infection index of Fusarium head blight of wheat (Triticum aestivum). State variables: FHE = First heads emerged; HEMG = proportion of heads emerged; ANT = daily proportion of anthers present; $\mathrm{ST}=$ proportion of susceptible tissue based on ANT and coefficients for susceptibility after peak flowering up to 14 days after flowering ends; IRES = Inoculum present on crop residues; GZ = relative density of a spore cloud; GIB = daily risk infection index. Rate variables: $\mathrm{HNG}=$ daily heading rate; $\mathrm{EXT}$ = daily anther's extrusion rate; INF = daily infection frequency; DIS = daily inoculum dispersal rate; Driving variables: $\mathrm{T}=$ daily mean temperature $\left({ }^{\circ} \mathrm{C}\right) ; \mathrm{RAD}=$ daily solar radiation $\left(\mathrm{MJ} / \mathrm{m}^{2} / \mathrm{dia}\right)$; $\mathrm{RH}=$ daily mean relative humidity $(\%)$ and $\mathrm{PREC}=$ daily precipitation $(\mathrm{mm})$.

An empirical rule was determined to define the longevity of anthers: the period of time they remain attached to wheat spikelets before dropping on the ground. In the model, this was translated into the following rule: anther's longevity is a minimum of two days. If daily solar radiation is $<10 \mathrm{MJ} / \mathrm{m}^{2} / \mathrm{dia}$ on the second or following day, anthers remain attached for an extra day up to a maximum of five days. The rule was based on empirical observations that reported an extension of flowering during a sequence of cloudy days suggesting anthers remained attached for a longer period (Reis, 1989; Vargas et al., 2000).

Hence, the proportion of anthers present in a single day (ANT) is a result of the summation of anthers extruded and attached in each cohort of heads subtracted by the anthers that were removed from the cohorts (no longer attached). The curve for ANT follows a bell shape and is regulated by temperature and solar radiation.

Coefficients were created to determine the proportion of susceptible tissue (ST) based on ANT and coefficients for post peak flowering infections. $\mathrm{ST}=\mathrm{ANT}$ until ANT reaches the peak and decreases to 0.25. After peak flowering, if ANT $<0.25$, then $\mathrm{ST}=0.25$ until $\mathrm{ANT}=0.01$. After flowering $(\mathrm{ANT}<0.01), \mathrm{ST}=0.25$ for the next seven days, while $\mathrm{ST}=0.10$ from eight to 14 days after flowering. These rules were created to account for late infections that may occur from the post-peak of flowering up to stages of kernel filling, as previously reported (Fernando et al., 1997; Del Ponte et al., 2003).

\section{Inoculum factor}

Models for predicting the daily relative density of a GZ spore cloud were developed by the observation on the night- and day-time deposition of G. zeae airborne inoculum in Passo Fundo, Brazil (Del Ponte et al., 2005). A linear equation was adjusted to the relative density of colony forming units that was observed during the night-time to estimate the relative density of a spore cloud [3].

$$
\mathrm{GZ}=(-0.6306+0.0152 \mathrm{RH}+0.1076 \mathrm{CRD})^{2}
$$

Where: $\mathrm{RH}=$ daily mean relative humidity $(\%) ; \mathrm{CRD}=$ dummy variable for a position of a rainy $(>0.3 \mathrm{~mm})$ day in a consecutive period of rainy days (for four consecutive days: $\mathrm{CRD}=1 ; 2 ; 2.5$; or 0.3 for each following day).

In that study, peaks of airborne inoculum at nighttime were associated with mean daily relative humidity values over $80 \%$ and rainfall occurrence. Hence, GZ is a fraction $(0<\mathrm{GZ}<1)$ that adjusts the daily infection index by accounting for a lower or higher inoculum pressure during an infection event.

\section{Environmental factor}

The INF calculates the proportion of susceptible tissue likely to be infected at any time. Simple rules were determined for the combination of daily records of rainfall and mean relative humidity to be compared to head wetness duration ranging from 30 to $48 \mathrm{~h}$. Every infection event is recorded in a two-day window by the following:

1) PREC $(>0.3 \mathrm{~mm})$ in both days with mean daily $\mathrm{RH} \geq$ $80 \%$ averaging the two days;

2) PREC in one day $(>0.3 \mathrm{~mm})$ with mean $\mathrm{RH} \geq 80 \%$ preceded or succeeded by a non rainy day with mean $\mathrm{RH} \geq$ $85 \%$.

An exponential model [4] was developed using data from literature for estimating infection frequency by $F$. graminearum under the effect of temperature $\left(10\right.$ to $\left.30^{\circ} \mathrm{C}\right)$ for $48 \mathrm{~h}$ of head wetness duration (Rossi et al., 2001).

$$
\mathrm{INF}=0.001029 \exp (0.1957 \mathrm{~T})
$$

Where: $\mathrm{T}=$ average mean daily temperature in the two-day window of the infection event

\section{Daily and accumulated infection index}

Four models were developed to calculate the daily infection index by combining and excluding factors [5]. The accumulated infection index (GIB\%) is calculated by the summation of partial infection indices by different models along the susceptible period [6]. A correction factor (x100) was used to express infection index as a percentage, since 
ANT is on a 0-1 scale.

$$
\begin{aligned}
& \mathrm{GIB} 1=\mathrm{ANT} * \mathrm{INF} \\
& \mathrm{GIB} 2=\mathrm{ANT} * \mathrm{INF} * \mathrm{GZ} \\
& \mathrm{GIB} 3=\mathrm{ST} * \mathrm{INF} \\
& \mathrm{GIB} 4=\mathrm{ST} * \mathrm{INF} * \mathrm{GZ}
\end{aligned}
$$

Where: $A N T=$ daily mean proportion of anthers during a two-day infection event (IE); ST = mean daily proportion of susceptible tissue during IE; INF = infection frequency at the second day of IE; GZ = mean G. zeae spore cloud density during IE;

$$
\mathrm{GIB} \%=\Sigma(\mathrm{GIB} * 100)
$$

Where: GIB is the daily infection index for each of the four models

\section{Model evaluation \\ Data collection: Observations of mid-flowering date} (50\% of heads showing anthers), disease incidence, severity and Fusarium-damaged kernels (\%FDK) were conducted in several spring wheat varieties grown in experimental plots in Embrapa Trigo, Passo Fundo (latitude $28^{\circ} 15^{\prime} \mathrm{S}$, longitude $52^{\circ} 24^{\prime} \mathrm{W}$, altitude $684 \mathrm{~m}$ ) in 1998-2001 and 2003, with two to three planting dates per year. For incidence and severity, a sample of 100 to 150 heads was hand-harvested in a planting row at early dough stage of grain development (28 to 35 days after mid-flowering) and taken to the laboratory. Incidence (proportion of infected heads in the sample) and severity (proportion of infected spikelets in the sample) values were determined using a visual scale for spring wheat (Stack \& McMullen, 1995). Severity is the same as the FHB index since it is the product of incidence and severity in infected heads. The FDK was evaluated in mature kernels randomly sampled after harvesting the plots. A sample of 30 cases ranging from very light to severe epidemics, representative of all years and planting dates, was selected. The initial sample was reduced to 20 cases, with similar mid-flowering dates (two-day window), which resulted in more than one cultivar per case in some instances. Thus, the dataset consisted of either single or average values of disease for different cultivars (Table 1). For FDK, data collection was performed in 1998-2000 only. Daily weather data was recorded at a standard weather station located approximately $1 \mathrm{~km}$ away from the experimental plots.

Model implementation: Software was developed to perform simulations using Java language. Since the model starts by entering the day when first heads emerge, preliminary runs were conducted for every case in order to match the simulated date when $50 \%$ of anthers were present at the observed mid-flowering date in the field. Simulation results starting from that matched date were regressed to observations.

Model validation: Since the models estimate an infection index, not disease level, regression was used to validate the model by verifying its adequacy in explaining disease levels. The different models were compared by analyzing the coefficient of determination for the regression between accumulated infection index and observations of the disease.

\section{RESULTS}

The FHB epidemics recorded in Passo Fundo varied among years and, in some instances, during the same year, reflecting the environmental dependence of the epidemics (Table 1). Light levels of epidemic were recorded in 1998. In 1999, no epidemic levels were found for the early plantings, while light epidemics occurred in the later plantings. In 2000, severe levels were recorded for late plantings, while light levels were recorded in 2001. For 2003, there was no epidemic level recorded. Among disease parameters, higher significant correlations $(P<0.01)$ were found between incidence and severity $(R=0.84)$ and incidence and FDK $(\mathrm{R}=0.82)$, whereas a lower correlation was observed between severity and FDK $(\mathrm{R}=0.60)$.

Regression between the accumulated infection index and observations for all four models showed they were able to explain disease variation except for FDK. The GIB3\% and GIB4\%, which consider a wider window of susceptibility and disease variation is better explained in the dataset. The inclusion of the GZ factor also improved model predictions as demonstrated by the increase in the coefficient of determination for the regression analysis (Table 2). Disease severity had the highest correlation parameter with GIB4\%, whereas incidence had a lower correlation.

Figure 2 shows the daily increase of GIB $4 \%$ index for two cases of severe (A -SEV=19.8\%) and light epidemics (B - SEV $=8.6 \%$ ). In A (mid-flowering on October 13, 2000), the model simulated 17 days of ANT $>0.01$ and five days of ANT $>0.5$ (peak flowering). Eight events of infection were calculated from day 284 to 291 covering the flowering period. A total of seven rainy days, mean RH of $87 \%$ and mean temperature of $19.6{ }^{\circ} \mathrm{C}$, were recorded for the eightday infection period resulting in an accumulated infection index of 15.4. A single infection event occurred at day 300 . In B (mid-flowering on October 2, 1998), the model simulated 16 days of ANT $>0.01$ and seven days of ANT $>0.5$. Three infection events were calculated for the days 276278 , right after peak flowering. A total of four consecutive rainy days, mean $\mathrm{RH} 84 \%$ and mean temperature of $17.1{ }^{\circ} \mathrm{C}$ were recorded for the three-day infection period which resulted in an accumulated index of 4.7. Another five infection events were recorded at post-flowering increasing the infection index from 4.7 to 6.0 .

The model was designed to simulate the part of the epidemic cycle corresponding to the percentage of tissue likely to be infected which showed a strong correlation with actual disease severity for the conditions of Passo Fundo, Brazil. The spread of the disease, upward and downward, in the primary infected spike tissues, which is a factor not 
TABLE 1 - Information on the dataset used for model validation. Fusarium head blight (FHB) of wheat (Triticum aestivum) was observed in experimental plots at Passo Fundo, RS, Brazil. Thirty observations were grouped by similarity of flowering date (two-day window) resulting in 20 epidemic cases used for validation of the GIBSIM model

\begin{tabular}{|c|c|c|c|c|c|c|}
\hline \multirow{2}{*}{ Year } & \multirow{2}{*}{ \# cases } & \multirow{2}{*}{ FD $^{1}$} & \multirow{2}{*}{ Cultivar } & \multicolumn{3}{|c|}{ FHB parameters $(\%)^{2}$} \\
\hline & & & & INC $^{3}$ & SEV $^{4}$ & FDK $^{5}$ \\
\hline 1998 & 1 & 240 & BR35 & $64^{5}$ & 8.8 & 20.0 \\
\hline 1998 & 2 & 257 & BR23, BR35 & 55 & 9.3 & 7.5 \\
\hline 1998 & 1 & 265 & CEP24 & 42 & 4.8 & 6.5 \\
\hline 1998 & 2 & 275 & BR23, BR35 & 63 & 8.6 & 13.0 \\
\hline 1998 & 2 & 278 & Frontana, CEP24 & 35 & 5.1 & 5.0 \\
\hline 1998 & 1 & 283 & BRS177 & 35 & 4.6 & 4.0 \\
\hline 1999 & 1 & 255 & BR18 & 15 & 2.4 & 1.5 \\
\hline 1999 & 1 & 259 & CEP24 & 8 & 0.8 & 0.5 \\
\hline 1999 & 1 & 280 & BR23 & 47 & 10.5 & 3.0 \\
\hline 1999 & 1 & 284 & Embrapa40 & 20 & 10.6 & 1.5 \\
\hline 2000 & 3 & 264 & BR23, BRS119, CEP27 & 51 & 5.8 & 12.0 \\
\hline 2000 & 1 & 271 & Frontana & 61 & 8.9 & 4.0 \\
\hline 2000 & 1 & 281 & BRS119 & 90 & 18.8 & 22.5 \\
\hline 2000 & 2 & 283 & BR23, Frontana & 93 & 26.3 & 14.5 \\
\hline 2000 & 1 & 286 & BRS120 & 82 & 19.8 & - \\
\hline 2001 & 1 & 245 & BR23 & 21 & 7.4 & - \\
\hline 2001 & 1 & 252 & BRS179 & 44 & 8.0 & - \\
\hline 2001 & 2 & 273 & BR35, BRS120 & 50 & 9.3 & - \\
\hline 2003 & 3 & 257 & BR23, Embrapa40, Fundacep29 & 11 & 1.7 & - \\
\hline 2003 & 3 & 282 & BRS Camboatá, BRS49, BR15 & 34 & 5.1 & - \\
\hline
\end{tabular}

${ }^{1} 50 \%$ of anthers present, expressed in day-of-year (Zadoks 65 )

${ }^{2}$ Single or mean values for the number of cases

${ }^{3}$ Infected heads out in sample of heads $(n=100)$

${ }^{4}$ Disease severity according to Stack \& Mac Mullen (1995). Same as FHB index.

${ }^{5}$ Fusarium damaged kernel $(n=100)$

taken into account in the model, may account for the increase and variation in severity levels. Figure 3 presents regressions between GIB4\% and SEV and GIB4\% and INC.The linear equation (Figure 3 ) suggests that $36 \%$ of disease increase may be due to new infected sites from spreading in infected heads. In order to make an interpretation of the model output easier, FHB severity classes were created, and disease severity values were estimated by the linear equation adjusted to the independent dataset used for validation (Table 2).

\section{DISCUSSION}

This is the first phenology-based model developed in South America that estimates daily infection indices over a simulated susceptible period and uses a factor accounting for inoculum density by infection time. The distinct weather conditions in different years and planting dates of the dataset alowed verification of the adequacy of the model in explaining variation of disease severity, even though the dataset is relatively small and has a gap of cases with severity falling between $11 \%$ to $19 \%$. The regression model may be useful for estimating severity range which is a simple way to alert for the potential risk and expected level of FHB outbreaks.

A better correlation with severity was not surprising given that model takes into account the proportion of susceptible tissue present during an infection event. Disease severity is a more realistic representation of the disease intensity in the field, as incidence accounts only for the proportion of heads infected that may have distinct portions of infected spikelets per spike. Hence, a moderate or severe disease incidence does not necessarily translate into high levels of severity. Temperatures below $15^{\circ} \mathrm{C}$ are not suitable for rapid spread of disease in an infected wheat head (Andersen, 1948). Final severity is also affected by the cultivar's resistance levels to the spread of the fungus fom the infected tissues (type II resistance) (Mesterhazy, 1997). In regards to FDK, heavily infected and lightweight kernels are frequently lost during harvesting and cleaning operations which affects the correlation between this parameter and visual disease data (Schaafsma, et al., 2001). This parameter showed the lowest correlation with accumulated infection index produced by the present model although it did present high correlation with disease incidence.

Despite the simplicity of the rules created to define an infection event based on daily rainfall and relative humidty, they seemed to be adequate and have biological meaning for the location that was evaluated. At temperatures ranging from 15 to $25^{\circ} \mathrm{C}$ (most of the range found in the dataset), a minimum of wetness duration from 24 to $48 \mathrm{~h}$ is 
A risk infection simulation model for Fusarium head blight...

TABLE 2 - Coefficient of determination for the regression analysis between simulated accumulated infection index (\%GIB) and Fusarium head blight of wheat (Triticum aestivum) parameters. The models used different factor to estimating accumulated infection index

\begin{tabular}{llccc}
\hline \hline \multirow{2}{*}{ Model } & \multirow{2}{*}{ Factor $^{1}$} & \multicolumn{3}{c}{ Disease parameter regressed (\%) } \\
\cline { 3 - 5 } & & SEV $^{\mathbf{2}}$ & INC $^{\mathbf{3}}$ & FDK $^{4}$ \\
\hline GIB\%1 & ANT, INF & 0.73 & 0.43 & 0.14 \\
GIB\%2 & ANT, INF, GZ & 0.79 & 0.46 & 0.16 \\
GIB\%3 & ST, INF, & 0.88 & 0.65 & 0.39 \\
GIB\%4 & ST, INF, GZ & 0.93 & 0.69 & 0.37 \\
\hline
\end{tabular}

${ }^{1} \mathrm{ANT}=$ daily proportion of anthers present; ST= daily proportion of susceptible tissue by correcting ANT after peak flowering and extending susceptible window to up to 14 days after flowering; INF= infection frequency; $\mathrm{GZ}=$ relative density of a Gibberella zeae spore cloud

${ }^{2}$ Mean proportion of head area infected in a sample of heads

${ }^{3}$ Proportion of heads infected out in a sample

${ }^{4}$ Fusarium damaged kernels

required for infections (Andersen, 19848). In the model, this window is expected every time rainfall occurs, and mean daily relative humidity is over $80 \%$ in a two-day window. Rainfall variables have been used as predictors in other FHB
TABLE 3 - Epidemic classes and correspondence of Fusarium head blight (FHB) of wheat (Triticum aestivum) severity and infection index estimated by GIBSIM model

\begin{tabular}{llcc}
\hline \hline $\begin{array}{l}\text { Severity } \\
\text { class }\end{array}$ & Description & FHB severity & GIB4\% ${ }^{\mathbf{1}}$ \\
\hline 0 & Non epidemic & $0.0-7$ & $0.0-4.5$ \\
1 & Light epidemics ${ }^{2}$ & $7.1-13.4$ & $4.51-8.9$ \\
2 & Moderate epidemics & $13.41-19.8$ & $8.91-13.3$ \\
3 & Severe epidemics & $>19.8$ & $>13.3$ \\
\hline
\end{tabular}

${ }^{1}$ Accumulated infection index $(\mathrm{x})$ is used to predict severity $(\mathrm{y})$ based on the following equation: $\mathrm{y}=0.97+1.36 \mathrm{x}\left(R^{2}=0.93 ; n=20\right.$ cases from five years $)$ ${ }^{2}$ Yield loss threshold based on results by Casa et al. (2003).

models (Moschini et al., 1996; Hooker et al., 2002). Moschini et al. (1996) used a number of events with two consecutive rainy days from heading to milk stages to predict FHB incidence. In a sequential work, the authors defined equivalence rules combining rainfall and relative humidity to estimate wetness duration from 12 to $72 \mathrm{~h}$ (Moschini et al., 2003). Hooker et al., (2002) used the number of rainy days $(>3 \mathrm{~mm})$, ranging from seven to ten days after the
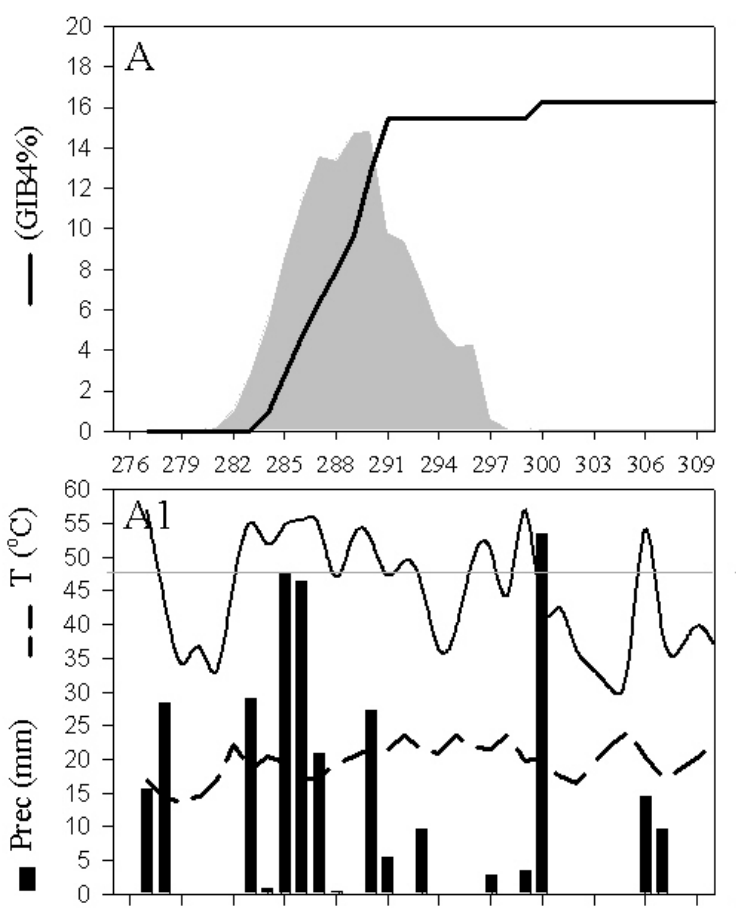

$276279282285288291294297300303 \quad 306309$

Day-of-year 2000

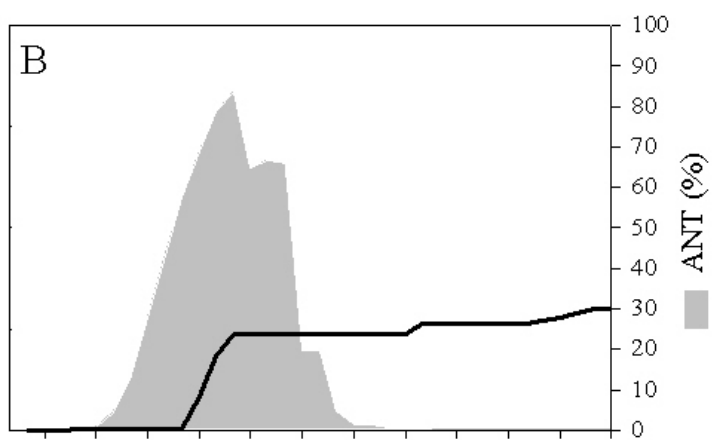

267270273276279282285288291294297300

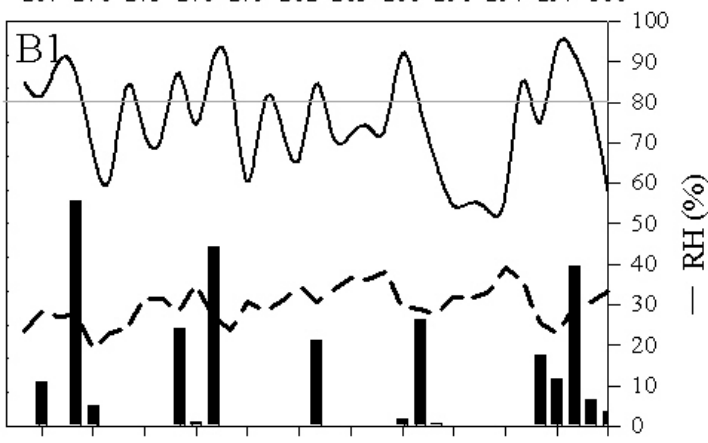

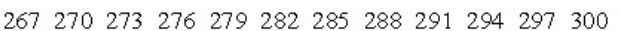

Day-of-year 1998

FIG 2 - Daily progress of Fusarium head blight of wheat (Triticum aestivum) infection index (GIB4\%) estimated by the GIBSIM model, a mechanistic process based simulation model, for two dates of mid-flowering: day-of-year 286 (Oct 13) of 2000 (A) and day-of-year 275 (Oct 2) of 1998 (B). Shaded area in A and B corresponds to percentage of anthers present (\%ANT). A1 and B1, corresponds to weather variables recorded for respectively A and B. Actual disease severity for $\mathrm{A}$ and $\mathrm{B}$ was $19.8 \%$ and $8.6 \%$, respectively. Prec $=$ daily precipitation; $\mathrm{T}=$ daily mean temperature; $\mathrm{RH}=$ daily mean relative humidity. 

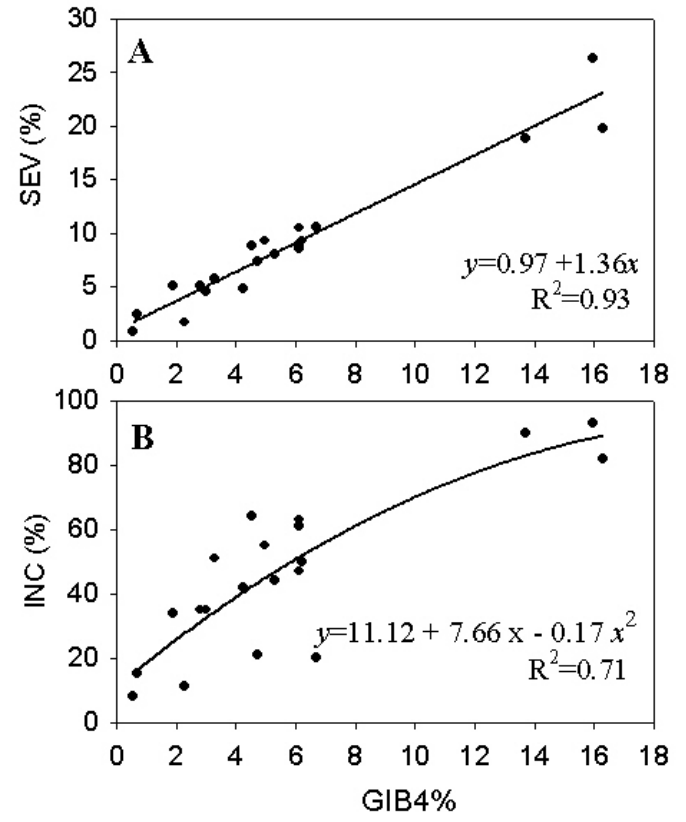

FIG. 3 - Regression between accumulated infection index (GIB4\%) generated by the GIBSIM model and some Fusarium head blight parameters of wheat (Triticum aestivum) (A) SEV: disease severity (B) Disease incidence. $\mathrm{N}=20$ cases recorded in experimental plots conducted in a location in Passo Fundo, southern Brazil over five years (1998-2001; 2003) and different planting dates.

heading date, which is around peak flowering, as one of three predictor factors in a model to estimate DON levels in harvested grains. A risk model used hours of rainfall by the time of flowering as one of the variables to predict likelihood of an FHB epidemic (De Wolf et al., 2003b). However, although it seems to reflect infection periods for Passo Fundo, the rule may need to be adjusted for locations with a different climate pattern (lower mean relative humidity but more hours of dew) and it would also be instructive to further use a wetness-based model or on-site measurement, for locations where hourly weather data is available. Another function could be used to consider an interaction factor for temperature and wetness duration. Only daily records of rainfall and relative humidity were available for the location of the dataset used for model validation.

Although GIBSIM well explained FHB severity for the location in this study, its potential use in other locations with different cropping and environmental conditions deserves further investigation. The model assumes inoculum as a non-limiting factor. In southern Brazil, most wheat is cropped under a no-till system, and airborne inoculum seems to be always present when the environment is highly suitable for infections (rainfall and $\mathrm{RH}>80 \%$ ), which corresponds well with peaks of spore detection (Reis, 1990; Panisson et al., 2002; Del Ponte et al., 2005). Other locations may be more dependent on exogenous inoculum sources, and infections may be absent or low if inoculum is not present or at very low levels. However, inoculum factors may use coefficients for specific conditions considering the availability of inoculum on the soil surface and/or previous crop. Wheat following wheat or other cereals, but especially following corn (Zea mays L.), resulted in higher disease severity (Dill-Macky \& Jones, 2000) and accumulation of DON in mature kernels (Schaafsma et al., 2001). Other empirically-derived FHB models use different parameters to account for previous crops which influences the risk for epidemics or DON levels (De Wolf et al., 2003b; Schaafsma \& Hoooker, 2003).

The heading and flowering models were empirically constructed with data observed in spring-wheat varieties cultivated under particular soil and weather conditions. A previous work reported that winter wheat varieties grown in central New York, USA, showed a more synchronous heading, resulting in a shorter period and, consequently, a shorter flowering time (Del Ponte et al., 2004a). In this case, a shift in the function for simulating heading progress would be necessary, as well as an adjustment to account for the effect of temperature on heading rate which is fixed in the present model.

A better characterization of post-flowering infections should be investigated further although the empirical coefficients to adjust host susceptibility after peak flowering contributed to increase the coefficient of determination. It was empirically assumed that at least $25 \%$ of head tissue remains susceptible for seven days after flowering ends, decreasing to $10 \%$ from seven to 14 days after flowering. For most cases, infection during flowering explained most of the variation in the dataset. This may be due to the fact that the model considering the effect of asynchronous heading, temperature and solar radiation effect in the presence of anthers simulated a not so short window of flowering. The simulated number of days with at least $1 \%$ of anthers present ranged from 15 to 19 days and five to eight days with $>50 \%$ of anthers present (peak flowering). This is consistent with previous studies that reported the flowering time as the most susceptible stage, and with empirically-derived models that use variables such as weather information from a short period (seven to ten days) around peak-flowering. Those models were $70-80 \%$ accurate in predicting epidemic occurrence or actual DON levels (Hooker et al., 2002; De Wolf et al., 2003a).

The simulation model proposed produced satisfactory results in explaining disease severity for very distinct weather conditions for one location. Hence, it is still necessary to verify its performance for other locations in southern Brazil. Process-based models may have some advantages over empirically-derived models, especially for complex pathosystems, in terms of adjustment of model components and because there is no need to construct a new model each time. This approach also has been used in another dynamic simulation model for FHB that produces daily infection risks for disease development and mycotoxin accumulation in infected tissues. Validation with a large field dataset showed that the risks produced by the model explained variations 
in the dataset producing satisfactory results (Rossi et al., 2003).

As it is, we foresee different applications for this model. The first would be in practical disease management. Fungicide spraying at the right time by making use of onsite predictions could effectively and economically prevent disease outbreaks. The use of a seven-day weather forecast would warn of outbreaks in advance. Alternatively, if a risk level of concern is anticipated, application of fungicides soon after infection, weather conditions permitting, would help in improving fungicide efficacy with a curative effect. In North America, an FHB epidemic is defined as over $10 \%$ of severity in order to guide fungicide applications (De Wolf et al., 2003a). Recent preliminary studies in Brazil have indicated that only one infected spikelet per head in a group of heads with the same disease intensity evaluated at dough stages, which is equivalent to $7 \%$ severity, resulted in significant reductions in kernel weight per head, one thousand seed weight and kernel infection (Casa et al., 2003). This situation (100\% incidence and $7 \%$ severity), however, is a rare occurrence in nature and more studies are needed. In this case, it is highly desirable to further validate the model with data from other locations in order to adjust parameters of the linear equation to better predict severity classes by regressing the infection index to actual observations. Parameters could be sensitive to the class of cultivar resistance, since there are clear differences in final severity for different cultivars which certainly deserves further investigation.

A second use for the model is in pre-harvest risk assessment once coupled to GIS systems and weather databases. Policy makers could base decisions on where to procuce crops based on an analysis of maps showing areas more likely to have a higher contamination with Fusarium spp. and mycotoxins. In countries with DON regulation, farmers may save money by avoiding transportation of high DON-contaminated wheat to millers. Another use of the model could be in climate change studies once the model is coupled to crop models by using the simulated flowering date. Historical weather scenarios would generate useful information for decision makers at different levels. Fernandes et al. (2004) coupled a preliminary version of the model to a wheat model (Cropsim) to study effects of climate change in FHB in wheat growing areas of Argentina, Uruguay and Brazil.

Lastly, students, extension agents and farmers may use this model as an educational tool for the understanding of FHB epidemics given the interactive nature and graphical capabilities of the disease simulator. Future work will keep focusing on the improvement of the model by the adjustment of its components with local experimentation and validation for other locations and more intensive use of computational resources to implement a true, web-based forecast system by using a seven-day weather forecast. Finally, once further validation proves useful, the system may be incorporated into practical production systems.

\section{ACKNOWLEDGEMENTS}

The research was supported by the Brazilian Council for Scientific and Technological Research (CNPq) with funding for the doctoral studies of the senior author; and by the Assessment of Impacts and Adaptation to Climate Change (AIACC) project. The authors gratefully acknowledge Maria Imaculada P. Lima and Gilberto Rocca da Cunha, from Embrapa Trigo, for respectively providing disease and weather data; Carlos R. Pierobom from Federal University of Pelotas, Edson C. Picinini from Embrapa Trigo and Gary C. Bergstrom from Cornell University for collaborations in previous work and suggestions during the development of the present work.

\section{LITERATURE CITED}

ANDERSEN, A.L. The development of Gibberella zeae headblight of wheat. Phytopathology 38:595-611. 1948.

BAI, G.H., SHANER, G. \& OHM, H. Inheritance of resistance to Fusarium graminearum in wheat. Theoretical and Applied Genetics 100:1-8. 2000

BAI, G.H., PLATTNER, R.D., DESJARDINS, A.E. \& KOLB, F. Resistance to Fusarium head blight and deoxynivalenol accumulation in wheat. Plant Breeding 120:1-6. 2001.

BOTTALICO, A. \& PERRONE, G. Toxigenic Fusarium species and mycotoxins associated with head blight in small-grain cereals in Europe. European Journal of Plant Pathology 108:611-624. 2002.

CASA, R.T., REIS, E.M., SCHEER, O., ZANATTA, T., CARDOSO, C. \& BOGO, A. Efeito do número de espiguetas gibereladas sobre o rendimento de grãos, peso de mil sementes e incidência de Fusarium graminearum em grãos de trigo. Fitopatologia Brasileira 28:S384. 2003. (Resumo)

DE WOLF, E.D., MADDEN, L.V. \& LIPPS, P.E. Risk assessment models for Fusarium head blight epidemics based on within-season weather data. Phytopathology 93:429-435. 2003a.

DE WOLF, E.D., MOLINEROS, J., WEI, C., LIPPS, P.E., MADDEN, L.V. \& FRANCL, L. Development and deployment of the next generation prediction models for Fusarium Head Blight. Anais, National Fusarium Head Blight Forum, St. Paul, MN, 2003b. pp.125-128

DEL PONTE, E.M., FERNANDES, J.M. C. \& BERGSTROM, G.C. Fusarium Head Blight and Deoxynivalenol accumulation in wheat inoculated at developmental stages from flowering through grain maturation. Anais, 2003 Fusarium Head Blight Forum, St. Paul, MN, 2003. pp.129-132.

DEL PONTE, E.M., FERNANDES, J.M.C., PAVAN, W. \& PIEROBOM, C.R. Simulação da dinâmica do florescimento do trigo como base para um modelo de simulação de giberela. Revista Brasileira de Agrociência 10:323-331. 2004a.

DEL PONTE, E.M., FERNANDES, J.M.C., PIEROBOM, C.R., BERGSTROM, G.C. Giberela do Trigo: Aspectos epidemiológicos e modelos de previsão. Fitopatologia Brasileira. 29:587-605. 2004b. DEL PONTE, E.M., FERNANDES, J.M.C. \& PIEROBOM, C.R. Factors affecting density of Gibberella zeae inoculum. Fitopatologia Brasileira 30:55-60. 2005. 
DILL-MACKY, R. \& JONES, R.K. The effect of previous crop residues and tillage on Fusarium head blight of wheat. Plant Disease 84:71-76. 2000.

FERNANDES, J.M.C. \& PAVAN, W. A phenology-based predictive model for Fusarium Head Blight of Wheat. Anais, 2002 National Fusarium Head Blight Forum, Erlanger, KY, USA, 2002. pp.154158.

FERNANDES, J.M., CUNHA, G.R., DEL PONTE, E., PAVAN, W., PIRES, J.L., BAETHGEN, W., GIMENEZ, A., MAGRIN, G. \& TRAVASSO, M.I. Modelling Fusarium Head Blight in wheat under climate change using linked process-based models. In: Canty, S.M., Boring, T., Wardwell, J. \& Ward, R.W. (Eds.). 2nd International Symposium on Fusarium Head Blight; incorporating the 8th European Fusarium Seminar; 2004, 11-15 December; Orlando, FL, USA. Michigan State University, East Lansing, MI. 2004. pp.441-444.

FERNANDO, W.G.D., PAULITZ, T.C., SEAMAN, W.L. \& MARTIN, R.A. Fusarium head blight susceptibility of wheat inoculated at different growth stages. Phytopathology 87:S30. 1997. (Abstract).

HART, L.P., PESTKA, J.J. \& LIU, M.T. Effect of kernel development and wet periods on production of deoxynivalenol in wheat infected with Gibberella zeae. Phytopathology 74:14151418. 1984

HOOKER, D.C., SCHAAFSMA, A.W. \& TAMBURINCILLINCIC, L. Using weather variables pre- and post-heading to predicting deoxynivalenol content in winter wheat. Plant Disease 86:611-619. 2002a.

LIMA, M.I.P.M., FERNANDES, J.M.C. \& PICININI, E.C. Avaliação da resistência à giberela em trigo. Fitopatologia Brasileira 25:30-35. 2000.

McMULLEN, M., JONES, R. \& GALLENBERG, D. Scab of wheat and barley: A re-emerging disease of devastating impact. Plant Disease 81:1340-1348. 1997.

MESTERHAZY, A. Breeding of resistance to Fusarium head blight of wheat. In: Dubin, H.J., Gilchrist, L., Reeves, J. \& McNab, A. (Eds.) Fusarium Head Blight. Mexico. CIMMYT. 1997. pp.79-85.

MILLER, J.D., CULLEY, J., FRASER, K., HUBBARD, S., MELOCHE, F., OUELLET, T., SEAMAN, W. L., SEIFERT, K. A., TURKINGTON, K. \& VOLDENG, H. Effect of tillage practice on Fusarium head blight of wheat. Canadian Journal of Plant Pathology 20:95-103. 1998.

MOSCHINI, R.C. \& FORTUGNO, C. Predicting wheat head blight incidence using models based on meteorological factors in Pergamino, Argentina. European Journal of Plant Pathology 102:211-218. 1996.

MOSCHINI, R.C., GALICH, M.T.V., ANNONE, J.G. \& POLIDORO, O. Enfoque fundamental-empírico para estimar la evolución del indice de Fusarium en trigo. RIA 31:39-53. 2002. PANISSON, E., REIS, E.M. \& BOLLER, W. Quantificação de propágulos de Gibberella zeae no ar e infecção de anteras em trigo. Fitopatologia Brasileira 27:484-488. 2002.

PANISSON, E., REIS, E.M. \& BOLLER, W. Quantificação de danos causados pela giberela em cereais de inverno, na safra 2000, em Passo Fundo, RS. Fitopatologia Brasileira 28:189-192. 2003. PICININI, E.C. \& FERNANDES, J.M.C. Efeito da época de pulverização com fungicidas sobre o controle de Gibberella zeae em trigo. Comunicado Técnico, Embrapa Trigo, Passo Fundo. 2001.

REIS, E.M. Caracterização da população de Fusarium graminearum ocorrente no Sul do Brasil. Fitopatologia Brasileira 11:527-533. 1986.

REIS, E.M. Fusariosis: biologia y epidemiologia de Gibberella zeae en trigo. In: Kohli, M.M. (Ed.) Taller sobre la fusariosis de la espiga en America del Sur. Mexico. Cimmyt. 1989. pp.97-102 REIS, E.M. Effects of rain and relative humidity on the release of ascospores and on the infection of wheat heads by Gibberella zeae. Fitopatologia Brasileira 15:339-343. 1990.

REIS, E.M., BLUM, M.M.C. \& CASA, R.T. Controle químico de Gibberella zeae em trigo, um problema de deposição de fungicidas em anteras. Summa Phytopathologica 22:39-42. 1996.

ROSSI, V., RAVENETTI, A., PATTORI, E. \& GIOUSUE, S. Influence of temperature and humidity on the infection of wheat spikes by some fungi causing Fusarium head blight. Journal of Plant Pathology 83:189-198. 2001.

ROSSI, V., GIOUSUE, S., PATTORI, E., SPANNA, F \& DEL VECHIO, A. A model estimating the risk of Fusarium head blight on wheat. EPPO Bulletin 33:421425. 2003.

SCHAAFSMA, A.W., TAMBURINC-ILLINCIC, L., MILLER, J.D. \& HOOKER, D.C. Agronomic considerations for reducing deoxynivalenol in wheat grain. Canadian Journal of Plant Pathology 23:279-285. 2001.

STACK, R.W. \& MCMULLEN, M. A visual scale to estimate severity of Fusarium head blight in wheat. Extension Publication PP-1095. North Dakota State University Extension Service. 1995.

SUTTON, J.C. Epidemiology of wheat head blight and maize ear rot caused by Fusarium graminearum. Canadian Journal of Plant Pathology 4:195-209. 1982.

VARGAS, P.R., FERNANDES, J.M.C., PICININI, E.C. \& HUNT, L.A. Simulação de epidemia de giberela em trigo. Fitopatologia Brasileira 25:497-504. 2000.

$\mathrm{XU}, \mathrm{X}$. Effects of environmental conditions on the development of Fusarium ear blight. European Journal of Plant Pathology 109:683-689. 2003.

ZADOKS, J.C., CHANG, T.T. \& KONZAK, C.F. A decimal code for the growth stages of cereals. Weed Research 14:415-421. 1974. 